
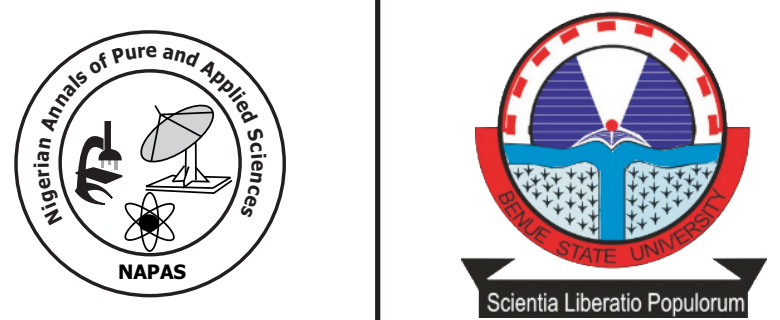

\title{
Acute Toxicity Study and Comparative effect of Kigelia Pinnata (Cucumber Tree) Ethanolic leaf extract on Serum Lipid profile of Albino Wistarrats treated fat diet.
}

\author{
Tarnande, C. I. and Uboh, F. \\ Department of Biochemistry, \\ Faculty of Basic Medical Sciences, \\ University of Calabar, Calabar, Nigeria.
}

\section{Abstract}

The aim of this study was designed to evaluate the activity of the Kigelia Pinnata ethanolic leaf extract on the serum lipid profile of male albino Wistar rats exposed to a fat diet. Kigelia Pinnata leaves were obtained, air dried, powdered and extracted in a Soxhlet apparatusin 400ml ethanol solution. Hypolipidaemic activity studies on rat models fed with palm oil and coconut milk was conducted. The acute toxicity test of the extract was carried out by the lorke's method. Results showed that Kigelia Pinnata ethanolic leaf extract significantly lowered $(\mathrm{P}<0.05)$ plasma Total Cholesterol $(\mathrm{TC})$, Low Density Lipoprotein (LDL)-Cholesterol and Triacylglycerol (TG) and significantly $(\mathrm{P}<0.05)$ increased plasma High Density Lipoprotein (HDL)-Cholesterol. Toxicity studies suggested that, the extract was safe at the doze $2000 \mathrm{mg} / \mathrm{kg}$. Overall findings from this study showed that the ethanolic extract exhibited hypolipidaemic activity and may possess cardio-protective properties.

Keywords: Kigelia Pinnata, Hyperlipidaemia, Hypolipidaemia, Lorke's method. 


\section{Introduction}

The Universal role of ethnobotanicals in ameliorating disease conditions, therefore providing useful folk healthcare delivery is exemplified by their relevance in several areas of health care systems. Pharmacognosy, the scientific study of medicinal plants, therefore remains the hub of pharmacopoeial identification, modern pharmacological isolation and testing procedures that provide new plant drugs as purified substances in medicine (Shellard et al., 1980). Historically, development of potent drugs as novel compounds in orthodox medicine stems from thorough ethnopharmacological screening of popular traditional plant medicines and herbal concoctions (Chadwilk and Marsh, 1993).

Kigelia pinnata, otherwise called Kigelia Africiana, but, commonly and coloqually known as cucumber tree, sausage tree, or worsboon is a huge enthnomedicinal plant that has found its way on the tables of ethnophamacologic laboratories for its attractive metabolomic profile (Arkhipov et al, 2014).

Recently, Kigelia pinnata has been demonstrated to be great in Forklore medicines (Houghton, 2007). Traditionally, the plant is used in the treatment of stroke, hypertension, diabetes, Malaria, Dysentery, skin disease, epilepsy, gynecological problems, inflammatory disorders, worm infestations, respiratory distress and ulcerative conditions (Houghton, 2007). Pharmacological investigations on the bark, roots, fruit and leaves extract of the plant showed that Kigelia pinnata has profound antileprotic activity (Lal and Yadar, 1983), microbial growth inhibition (Akunyili et al., 1991), anti-neoplastic potentials (Msouth et al, 1983), gyneacological healing properties (Dada, et al 2010), central nervous system activity (Shalini et al., 2014) and antidiabetic effects (Patel, et al., 2012).

Palm oil is an ideal household cooking ingredient. It is used in commercial food and cosmetic industries in huge quantities due largely to its high oxidative stability properties (Cheman et al., 1999). Palm oil is a fatty liquid; and as with all fats, it is composed of fatty acids andglycerol backborneheld together by an ester bond (Chatterjea and Shinde, 2008). Palm oil contains approximately a unit unsaturated and saturated fatty acids ratio. Palmitic and stearic acid account for the saturated fatty acid content of palm oil with $45 \%$ and $5 \%$ composition, respectively. Whereas oleic and linoleic acids account for the unsaturated fatty acids content of palm oil with $36.6 \%$ and 9.1\% composition, respectively (Gunstone and Norris, 1983). This oil as a dietary regimen has profound impact on health and disease (Hassan,
1988).

Coconut milk is produced from the endosperm or meat of the coconut fruit and has good role in diet with good physiological attributes (Enig, 2005). Coconut milk contains approximately $20 \%$ of virgin coconut oil and $80 \%$ of water (Nevin and Rajamoham, 2009).

Coconut oil consists predominantly of saturated fatty acids and to a lesser extent monounsaturated and polyunsaturated fatty acids (FAs). Saturated fatty acids include; lauric acid, capric acid; caprylic acid; myristic acid and palmitic acids, while the mono and polyunsaturated fatty acids include oleic and linoleic acids respectively (Gregorio, 2005). Coconut oil also contains traces of certain derivative like betaines, polyol esters and polyphenols like galic acid (Nevin and Rajamohan, 2004). Traditionally coconut oil is used by diversecultures for the treatment of abscesses, asthma, baldness, bronchitis, flu, weakness, weight loss; hair care and skin infections (Enig,2005).

Palm oil and coconut oil therefore remain a major source of dietary lipids in many nations, particularly the developing nations (chandrasekhran 1999). Critical assessment of the nutritional value of lipids point to increased patho physiological alteration in metabolism and health (Ross, 1992). A positive correlation exist between the amount, type and nature of dietary lipids and metabolic syndrome-obesity, diabetes and cardiovascular diseases (Goh, 2006).

Increased dietary lipids lead to a build-up of abnormal serum lipids concentration in blood; a condition referred to as hyperlipidaemia or dyslipidemias (Chatterjea and Shinde, 2008). Dyslipidemias can be caused directly by genetic defects or through dietary imbalance, or as a secondary pathology due largely, to a consequence of other disease (Bastiste and Schaefer, 2002).

Dyslipidemia have been demonstrated as a major risk factor in cardiovascular and cerebrovascular complications (Roberts, 1995; Tunstall, 1994). It has been reported that dyslipidemias also induce liver damage and kidney dysfunction (Bugianesi and Leone, 2002).

\section{Aims and Objective of the Study}

i. To determine the comparative effect of Kigelia pinnata ethanolic leaf extracts on serum lipid profile of rats orally administered palm oil and coconut milk.

ii. To determine the comparative effect of Kigelia pinnata ethanolic leaf extract on change in body weight and estimation of 
organ weight of rats orally administered palm oil and coconut milk.

\section{Materials and methods \\ Collection and Identification of Plant Sample}

Kigelia pinnata leaves were obtained in the month of August, 2015 from Kumbur Aga forest Mbakume, in Gwer-East Local Government Area of Benue State. The plant leaves were identified and authenticated by a Botanist in the Department of Botany, University of Agriculture Makurdi, Benue State.

\section{Preparation of plant extract and oil source}

The Kigelia pinnata leaves obtained from Kumbur Aga forest were properly washed and rinsed with tap water to remove the debris. The leaves were air-dried for two weeks in the Department of Biochemistry, University of Calabar, - Calabar, - Nigeria. The dried leaves were then ground to powder using mechanical grinder. About $250 \mathrm{~g}$ of the dried leaf powder was extracted using the soxhlet apparatus, concentrated by evaporation and stored in the refrigerator for use. Fresh palm oil and coconut fruits were obtained from Akim Market in Calabar. The oil was also stored in the refrigerator for use, while coconut fruits were opened, the meat removed and grated. The grated meat was squeeze and filtered using Muslim cloth to obtain the coconut milk and also stored in the refrigerator for use.

\section{Animal Handling and Treatment.}

Forty Eight (48) male albino Wistar rats weighting between 120-160grams, were obtained from the Animal farm of the Department of Biochemistry, University of Calabar, Calabar, Nigeria. The rats were kept in the animal house of the Department of Biochemistry, University of Calabar. Rats were then distributed randomly into eighty (8) groups with six animals per group and acclimatizedfor two (2) weeks under an experimental condition of 12 hours light -dark cycle and prevailing ambient temperature of $25^{\circ} \mathrm{C}$. The animals were fed with the normal rat chow and allowed access to tap water ad libitum.

\section{Experimental design and animals groups distribution}

Table 1: Distribution of Rats into Experiment groups

\begin{tabular}{|c|c|c|}
\hline Group & Number & Treatment \\
\hline 1 & 6 & Normal rat chow (Control) (CO) \\
\hline 2 & 6 & $0.49 \mathrm{~g} / \mathrm{kg}$ body weight $\mathrm{KP}$ \\
\hline 3 & 6 & $5 \mathrm{ml} / \mathrm{kg}$ body weight $\mathrm{PO}$ \\
\hline 4 & 6 & $5 \mathrm{ml} / \mathrm{kg}$ body weight $\mathrm{CM}$ \\
\hline 5 & 6 & $2.5 \mathrm{ml} \mathrm{kg}$ body weight each $\mathrm{PO}$ and $\mathrm{CM}$ \\
\hline 6 & 6 & $\begin{array}{l}0.22 \mathrm{~g} / \mathrm{kg} \text { body weight of KP and } 2.5 \mathrm{ml} . \mathrm{kg} \text { body weight of } \mathrm{PO} \text { after ( } 1 \text { hour } \\
\text { of KP) }\end{array}$ \\
\hline 7 & 6 & $\begin{array}{l}0.22 \mathrm{~g} / \mathrm{kg} \text { body of } \mathrm{KP} \text { and } 2.5 \mathrm{ml} / \mathrm{kg} \text { body weight of } \mathrm{CM} \text { (after } 1 \text { hour of } \mathrm{KP} \\
\text { administration). }\end{array}$ \\
\hline 8 & 6 & $\begin{array}{l}0.22 \mathrm{~g} / \mathrm{kg} \text { body weight of KP and } 2.5 \mathrm{ml} . \mathrm{kg} \text { body weight each of } \mathrm{PO} \text { and } \mathrm{CM} \\
\text { (after } 2 \text { hours of KP administration). }\end{array}$ \\
\hline
\end{tabular}

Treatment with the respective test substances (KP, PO, CM and CO) was done orally using intragastic cannula per day. All treatments lasted for 30 days. KP (Kigelia pinnata) PO (Palm Oil) CM (Coconut Milk) $\mathrm{CO}$ (Control).

\section{Collection and preparation of blood sample for serum lipids profile analyses.}

Blood samples were obtained from rats by cardiac puncture under chloroform vapour anaesthesia, 24-hours after the last day of experimental treatment. Blood samples for analyses were collected into sterile, plain bottles.

The blood sample collected for analyses were spinned in a centrifuge at $3000 \mathrm{rpm}$ for 10 minutes to obtain the serum. Serum was collected in dry sample containers, stored in a refrigerator and used forserum lipids profile estimation.Serum sampleswere analyzed spectrophotometrically for
Triacylglycerol,Total cholesterol, High density lipoprotein using respective kits - UV-visible spectropholometer. VLDL-C and LDL-C were calculated using Friedwald's equation. $\mathrm{VLDL}=\mathrm{LDL}=\mathrm{TC}-(\mathrm{HDL}+\mathrm{VLDL})$

\section{Estimation of Body and Organ Weights.}

Body weights of the experimental rats were recorded both in the treated and control groups at the beginning of the experiment (day 0) and sequentially on every $5^{\text {th }}$ day, during the treatment period. Kidney and liver were removed and their respective weights estimated for every rats 
sacrificed.

\section{Acute Toxicity $\left(\mathbf{L D}_{5_{0}}\right)$ determination of Kigelia pinnata leaf extract.}

The $\mathrm{LD}_{5_{0}}$ was carried out using the Lorke's method (1993). It involved a total number of thirteen (13) male mice. The test was carried out in phases. Phase one employed a total of nine (9) mice, grouped into three (3), i.e. three mice per group. Group one received $500 \mathrm{mg} / \mathrm{kg}$ of the extract, group two received $1000 \mathrm{mg} / \mathrm{kg}$ of the extract and group three received $2000 \mathrm{mg} / \mathrm{kg}$ of the extract. All administrations were done by intraperitoneal route. The animals were monitored for four (4) hours, then intermittently for the next 6 hours and over a period of 24-hours. The numbers of dead animals were noted. From the result of phase one, the second phase (II) was carried out. In phase II a total of four Mice were used and group into four groups, one mice per group. Group one received $3000 \mathrm{mg} / \mathrm{kg}$, group received $4000 \mathrm{mg} / \mathrm{kg}$ and group three received $5000 \mathrm{mg} / \mathrm{kg}$ of the extract, and group four received $1 \mathrm{ml}$ of tween 80 .

The animals were then monitored for any death. The $\mathrm{LD}_{50}$ was then calculated using the relationship.

$$
\operatorname{Ld}_{50}=\sqrt{D \mathbb{Q X} D}
$$

$\mathrm{D}_{0}=$ Highest dose that gave no mortality

$\mathrm{D}_{100}=$ Lowest dose that produce mortality.

\section{Statistical Analysis}

Data are presented as mean \pm Standard error of mean (SEM). Results were analysed using oneway analysis of variance (ANOVA) with SPSS window. Student " $t$ " test was further used for pairwise comparison, and differences were considered significant at $\mathrm{P}<0.05$ ( $5 \%$ level of confidence limit). The normal control group was compared with the fat-diet fed group and all other treatment groups were compared with the fat-diet fed group.

\section{Result}

Acute Toxicity Test $\left(\mathrm{LD}_{50}\right)$ for ethanolic leaf extracts of Kigelia pinnata

Plant by Lorke's method

Table 2: The Results of acute toxicity test of Kigelia pinnata extract on male mice.

\begin{tabular}{lcc}
\hline phases & Doses $(\mathbf{m g} / \mathbf{k g})$ & Number of Death \\
\hline 1 & 500 & $0 / 3$ \\
& 1000 & $0 / 3$ \\
2 & 2000 & $0 / 3$ \\
& 3000 & $0 / 1$ \\
& 4000 & $1 / 1$ \\
Control & 5000 & $1 / 1$ \\
\hline
\end{tabular}

$\left(\mathbf{L d}_{50}\right)=\sqrt{2000 \times 3000}$

$=2449.49 \mathrm{mg} / \mathrm{kg}$.

\section{Effect of Kigelia pinnata leaf extract on Serum lipids profile of albino \\ Wistar rats orally administered palm oil and coconut milk.}

The comparative results of serum lipid (TC, TG, LDL, and HDL) profile of rats orally administered Kigelia pinnata extract, palm oil and coconut milk showed significant $(\mathrm{P}<0.05)$ change in Total cholesterol (TC), Triacylglycerol (TG),Low density lipoprotein (LDL)-Cholesterol and(HDL)-Cholesterol relative to the control group (1) and fat-diet fed group (3) as depicted in table 3 . 
Table 3:

\begin{tabular}{llllll}
\hline $\begin{array}{l}\text { Group } \\
\text { Control }\end{array}$ & $\begin{array}{l}\text { TC } \\
(\mathrm{mg} / \mathrm{dl})\end{array}$ & $\begin{array}{l}\text { TG } \\
(\mathrm{mg} / \mathrm{dl})\end{array}$ & $\begin{array}{l}\text { HDL-C } \\
(\mathrm{mg} / \mathrm{dl})\end{array}$ & $\begin{array}{l}\text { LDL-C } \\
(\mathrm{mg} / \mathrm{dl})\end{array}$ & $\begin{array}{l}\text { VLDL-C } \\
(\mathrm{mg} / \mathrm{dl})\end{array}$ \\
\hline I & 132.38 & 65.77 & 44.06 & 75.03 & 13.29 \\
& \pm 0.90 & \pm 0.63 & \pm 0.90 & \pm 0.58 & \pm 0.83 \\
II & 101.25 & 50.13 & 50.73 & 42.49 & 10.05 \\
& \pm 1.28 & $\pm 1.13^{*}$ & \pm 0.67 & \pm 0.96 & \pm 1.01 \\
III & 135.40 & 66.43 & 37.91 & 84.34 & 13.15 \\
& $\pm 1.24^{*}$ & \pm 1.23 & $\pm 1.33^{*}$ & $\pm 1.21^{*}$ & \pm 1.21 \\
IV & 87.44 & 58.25 & 57.38 & 24.41 & 11.65 \\
& $\pm 1.13^{*}$ & $\pm 1.88^{*}$ & \pm 1.25 & $\pm 1.11^{*}$ & $\pm 1.03^{*}$ \\
V & 117.30 & 60.46 & 56.99 & 48.22 & 12.09 \\
& $\pm 1.54^{*}$ & $\pm 0.64^{*}$ & $\pm 0.87^{*}$ & $\pm 0.88^{*}$ & $\pm 0.86^{*}$ \\
VI & 109.28 & 60.88 & 48.81 & 48.29 & 12.18 \\
& $\pm 1.85^{*}$ & $\pm 1.72^{*}$ & $\pm 1.10^{*}$ & $\pm 0.76^{*}$ & $\pm 0.91^{*}$ \\
VII & 82.95 & 56.60 & 59.40 & 12.23 & 11.32 \\
& $\pm 1.85^{*}$ & $\pm 0.88^{*}$ & $\pm 0.71^{*}$ & $\pm 0.83^{*}$ & $\pm 0.80^{*}$ \\
VIII & 79.44 & 57.04 & 58.96 & 12.07 & 11.41 \\
& $\pm 1.10^{*}$ & $\pm 0.84^{*}$ & $\pm 0.86^{*}$ & $\pm 0.85^{*}$ & $\pm 0.72^{*}$ \\
\hline
\end{tabular}

Values are expressed as mean \pm SEM, $\mathrm{n}=6$. Values are significantly differentwhen group II were compared with group III and group III compared with groups V, VI VII, and VIII. $* \mathrm{P}<0.05$.

Table 4: Change in body weights of groups in 30days

\begin{tabular}{llllll}
\hline \multicolumn{1}{c}{ Group } & \multicolumn{1}{c}{ Week 1 $(\boldsymbol{g})$} & \multicolumn{1}{c}{ Week 2 $(\boldsymbol{g})$} & \multicolumn{1}{c}{ Week 3 $(\boldsymbol{g})$} & Week 4 $(\boldsymbol{g})$ & Week 5 $(\boldsymbol{g})$ \\
\hline Control & 134.75 & 147.13 & 159.40 & 168.70 & 180.63 \\
& \pm 0.61 & \pm 0.95 & \pm 0.88 & \pm 0.09 & \pm 0.68 \\
II & 153.63 & 166.13 & 172.90 & 187.08 & 196.35 \\
& \pm 0.57 & \pm 0.74 & \pm 0.84 & \pm 0.95 & \pm 0.52 \\
III & 141.90 & 166.55 & 179.43 & 187.30 & 210.13 \\
& \pm 1.37 & \pm 0.59 & \pm 1.35 & \pm 1.21 & \pm 0.09 \\
IV & 142.33 & 160.05 & 171.00 & 180.73 & 191.29 \\
& \pm 1.23 & \pm 0.97 & \pm 1.28 & \pm 0.56 & \pm 0.85 \\
V & 123.80 & 136.75 & 137.65 & 140.05 & 165.30 \\
& \pm 1.10 & \pm 1.60 & \pm 1.65 & \pm 1.64 & \pm 0.35 \\
VI & 138.87 & 146.70 & 158.23 & 170.10 & 190.25 \\
& \pm 1.20 & \pm 1.16 & \pm 1.52 & \pm 0.98 & \pm 0.35 \\
VII & 141.35 & 150.38 & 161.48 & 171.80 & 191.18 \\
& \pm 1.23 & \pm 1.07 & \pm 1.13 & \pm 0.09 & \pm 0.89 \\
VIII & 159.87 & 159.53 & 161.13 & 173.40 & 189.67 \\
& \pm 1.26 & \pm 1.32 & \pm 0.90 & \pm 1.48 & \pm 0.82 \\
\hline
\end{tabular}

Value are expressed as mean \pm SEM, $\mathrm{n}=6$ 
Table 5: Liver and Kidney weights of rats on sacrificed

\begin{tabular}{lll}
\hline Group & Kidney weight $\mathbf{( g )}$ & Liver weight $\mathbf{( g )}$ \\
\hline Control & 1.15 & 6.90 \\
& \pm 0.09 & \pm 0.41 \\
II & 1.33 & 6.70 \\
& \pm 0.15 & \pm 0.66 \\
III & 1.25 & 7.08 \\
& \pm 0.09 & \pm 0.46 \\
IV & 1.23 & 6.43 \\
& \pm 0.10 & \pm 0.38 \\
V & 1.00 & 6.60 \\
& \pm 0.05 & \pm 0.30 \\
VI & 1.27 & 6.63 \\
& \pm 0.12 & \pm 0.17 \\
VII & 1.19 & 6.68 \\
& \pm 0.17 & \pm 0.46 \\
VIII & 1.10 & 6.60 \\
& \pm 0.14 & \pm 0.64 \\
\hline
\end{tabular}

Values are expressed as mean \pm SEM, $n=6$

\section{Discussion}

The result of the acute toxicity test of Kigelia pinnata leaf extracts indicate that, the extract did not produce any noticeable toxicity in the test models up to dose level of $3000 \mathrm{mg} / \mathrm{kg}$ body weight even after 48 -Hours, but produced toxic symptoms of restlessness, lost of appetite and mortalityat the dose level of $4000 \mathrm{mg} / \mathrm{kg}$ body weight and dose level $5000 \mathrm{~g} / \mathrm{kg}$ body weight. The Kigelia pinnata leaf extracts therefore has high lethal dose and could be safe for therapeutic purposes. This result partly agree with the report of, Azu and Duru (2012), that classified Kigelia pinnata plant as a non-toxicmedicinal plant but expressed the safe dose of $4000 \mathrm{~g} / \mathrm{kg}$ in contrast to this result that state the safe dose of the plant as $2000 \mathrm{mg} / \mathrm{kg}$ body weight.

Serum lipid profile studies have remained one of the most important diagnostic assessment of vascularities in key organs like the heart, brain, kidney, liver, pancreas and induced metabolic syndrome (Ginsberg 1994,1 Vaziri, 2009). Serum lipid profile analysis is often used to predict lipidbased abnormalities like cardiovascular and cerebrovascular complication (Glass and Witztum, 2001; Malasky and Alpert, 2002). Kigelia Pinnata ethanolic leaf extract demonstrates significant decrease in serum total cholesterol (TC), triacyglycerols (TG), low density lipoproteins (LDL) and increased high density lipoprotein (HDL)in male rats following 30 days of exposure to the extracts.

Comparative analyses of lipid parameters in the control group (I), Kigelia pinnata administered group (II), fat-diet fed group (III) and Kigelia Pinnata treated groups (VI, VII and
VIII) showed that Kigelia pinnata ethanolic extract, significantly $(\mathrm{P}<0.05)$ decreased levels of TC, TG, LDL-C andVLDL, but, significantly $(\mathrm{P}<0.05)$ increased HDL-C as compared to the control and fat-diet fed groups. A significant decrease in body and organ (liver and kidney) weights was also noticed with the Kigelia pinnata extract treated groups. Palm oil fed group significantly $(\mathrm{P}<0.05)$ increased $\mathrm{TC}, \mathrm{TG}, \mathrm{LDL}-\mathrm{C}$ and VLDL but significantly $(\mathrm{P}<0.05)$ decreased HDL-C. A significant increase in body and organ weights was also recorded with the palm oil fed group.

The result of this study suggest, Kigelia pinnata leaf extract may be cardio-protective as it raises serum HDL-C levels and decrease serum total cholesterol, triacylglcerols and LDL-C levels. Results also agree with the report of Preeti and Asheesh, (2011) that aqueous or ethanolic extract of the fruits of Kigelia pinnata raise HDL$\mathrm{C}$ but lowers total cholesterol and LDL-C in triton-induced hyperlipidaemic rats. The results also lend credence to investigation of Anowi et al., (2014) that the ethanolic leaf extract of Kigelia pinnata have potent analgesic and antiinflamatory properties. The possible mechanism of action of the anti-hyperlipidaemic potentials of Kigelia pinnata leaf extracts might be attributed to its high flavonoids, tannins and phenolic content. Flavonoids and phenolic compounds are potent antioxidants that may have prevented the oxidation of LDL-C in atherosclerosis (Onyemaecha et al, 2010). Another possible mechanism of action of Kigelia pinnata extract stem from its huge content of potent anti-oxidants that prevent infiltration and accumulation of fat by 
the liver hepatocytes. Polyphenols and flavonoids contained in Kigelia pinnata leaf extract have been demonstrated to activate adenosine monophosphate kinase and the phosphorylation of acetylCoA carboxylase, a key enzyme in fatty acid synthesis. Once phosphorylated, aacetyl CoA carboxylase is inhibited thereby preventing fatty acid synthesis hence ameliorating avenue for a fatty liver (Zang et al, 2004).

\section{Conclusion}

It may be concluded from the results of this study that; Oral exposure to Kigelia pinnata leaf extracts contain some active principles that may provide protection against lipid induced tissue injury, as indicated in decreased serum LDL, TC, TG and increased HDL levels. It may also be concluded from the findings to the study that Kigelia pinnata extract has no adverse effect on liver and kidney tissues, as indicated in the remodeling of the weights of these organs. Consumption of palm oil beyond certain amount may lead to obesity thereby predisposing the individual to metabolic crises.

\section{References}

Akah, P. A. (1998). Antidiarrhoeal activity of the aqueous leaf extract of Kigelia Africana experimental animal. J. Herbs spices Med. Plants 4(2): 31-38.

Akpanabiatu, M. I., Ekpa, O. D., Mauro, A. and Rizzo, R. (2001). Nutrient composition of Nigerian Palm kernel from Dura and Tenera varieties of the oil palm (Elais guinrrnsis). Food Chem. 72:17-177

Akunyili, D. N, Houghton, P. J., Roman, A. (1991). Antimicrobial activities of the stem of Kigelia pinnata, J. Ethnopharmacol. 35:173-177.

Anowi, C.F, Ihionu U. M. Obi P. E. (2014). An Investigation in the antipyuretic effects of the ethanol extract of the leaves of Kigelia Africana Int. J. of Adv. Phar. Sc. 2263-2268.

Arkhipov A. Sirdaarta J, Mathews, B. (2014). Melabolomic Profiling of Kifelia Africana extracts with anti-cancer activity by high vesolution tenderin mass spectroscopy. Indian J. of Pharm. 4:4.

Arunima S. and Rajamohan T. (2012). Virgin coconut oil improves hepatic lipid metabolism in rats-compared with copra oil, olive oil and sunflower oil. India J of Exp. Biol. 50:802-809.

Azu. O.O. and Duru, F.O (2012). Preliminary study on the antioxidant effectof Kigelia pinnata fruit extract in male SpraqueDawley rats. American Journal of Biotech.
9(9); 1374-1381.

Barnes J. Anderson L.A. Philipson JD. (2007). Herbal medicines, $3^{\text {rd }}$ edn. Pharmaceutical press, Lodon.

Bastiste, M.C. and Schaefer, E.J. (2002). Diagnosis and Management of lipoprotein abnormalities Nutr. Clin. Care 5(3); 289295.

Bruce, F. (2004) Healing miracles of coconut oil. Deejay: 33.

Bryines S. (2010). Introduction to coconut oil bioles and med. 116 (11) 1364-67.

Bugianesi, E. Leone N. (2002) Expanding the natural history of non-alcoholic steatohepatistis. Gastroenterology 123:134-140.

Chadwicks, N. and Marsh, K. (1994). Ethnobotany and the search for new drugs. Cibafoundation symposium; 185.

Champe P.C. and Harvey R.A Schmidley (2005). Lippincotts illustrated Biochemistry $4^{\text {th }}$ ed. Williams and Wilkins.

Chan, P.H, Fishman, R.A. Schmidley (1984). Release of Polyunsaturated fatty acids from phospholipids and derived free radicals. $J$ Neurosci Res. 12:595-605.

Chandrasekharan N. (1999). Changing concepts in lipid Nutrition in health and disease Med.J of Malaysia 54:408-428.

Chandrasekharan N.and Sundran K. Rona .C. (2000). Changing nutrition and health perspective on palm oil. Brunel. Int. Med. J. 2;417-427.

Chariandy, C.M, Seaforth R.H. Pollard G.V. (1999). Screening of Medicinal plants from Trinidad and Tobago for antimicrobial and insecticidal properties J. Ethnopharmacol. 64;265-270.

Chatterjea M.N, and Shinde R. (2008). Text book of Medical Biochemistry $7^{\text {th }}$ ed. Jaypee publishers New Delhi, India.

Cheman, Y.B. Liu., J.L., Jamilah, B., Rahman R. (1999). "Quality changes of RBD. Palm olein, soybean oil and their blend during deep-fat frying". Journal of Food lipids (3): 181-193.

Cynober, L.A (1995). Amino acid metabolism in health and nutrition disease. Boca Raton Fla. CRS. Press.

Dada A.A Adeparusi E.O. Alale O.V. (2010) Dietary dried Kigelia pinnata fruits meals as fertility enhancer in female Clarias gariepinus. Agric. Bio. Jof Am. 1(5);791.

Engler, M. B. (1992). Effects of omega-3 omega-6 and omega-9 fatty acids onvascular smooth muscle tone. Eur. J. Phatmacol 215:325328 
Enig M.G. and Fife B. (2004). Coconut oil and heart disease. Deejay: 33.

Enig MG. (2005). Coconut cures: preventing and treating common health problems with Coconut, Avery Trade, New York, Ny, USA, $4^{\text {th }}$ Edition.

Ginsberg H.D. (1994). Lipoprotein Metabolism and its relationship to atherosclerosis. Med. Clin. North Am. 78(1): 1-20.

Glass, C.K. and Witzum, J.L. (2001) Atherosclerolsis; The road ahead. Cell. 104 (4) 503-516.

Goh, S.H. (2006). Oil and fat in nutrition and healthy; chemistry, digestion and metabolism. Melay. Oil Sci. Techn. 15;4365.

Gregorio C.G. (2005). Fatty acids and derivatives from coconut oil John Willey and Sons, Inc. Hoboken pp 1-56.

Gropper S.S, Smith J.L. Groff, J.L. (2005) Advanced nutrition and human metabolism. $4^{\text {th }}$ ed. Thomson Wadsworth publishers.

Gunstone F.D and Norris F.A (1983). Lipids in food; Chemistry, Biochemistry and technology. Oxford; pergamon press, pp40,144-146.

Gunstone F.D and Harwood J.L(1986).The lipid Handbook. London; Chapman and Hall,pp;76-78.

Guyton, J.R. (2007). Niacin in cardiovascular preventive mechanisms, efficacy, safety. Curr. Opin. Lipodl. 18 (4).

Harris, W. (1997). Fatty acids and serum lipoproteins: human studies $A$. M. J. Clin Nutr 56, 1645S-54S.

Hassan, A.H (1988). Palm Oil and health. The planter 64 (752): 505-519.

Havel, R.J. And Kane, J.P. (2001). Introduction; structure and metabolism of plasma lipoproteins. $8^{\text {th }}$ ed. McGraw-Hill., New York.

Hayes K. C. and Khosla, P. (1992). Dietary fatty acids thresholds and cholesterolemia. FASED

Hopkins P.N. and Hunt S.C. (1998). Lipoprotein ca Interations with lipid and non-lipid risks factors in patients with early onset of Coronary artery disease. Atherosclerosis 141(2): 333145.

Hornstral G. (1990). Effect of dietary lipids in some aspects of the cardiovascular risk profile, in G Ziants

Houghton, P. J. (2007). The sausage tree (kigelia pannata), Ethnobotany and recent scientific work. Afr. Botanicals 1-10.

Houghton, P.J. Photioun, A., Uddin, S., Shah, P., Browing, M., Jackson, S.J., (1994). Activity of extracts of Kigelia pinnata against melanoma and renal carcinoma cell lines. Planta medical. 60 (5): 430-433.

Hutchings, A. Scott A.H. Lewis G. (1996). Zulu medical plants. An inventory university of nasal press; 55-54.

Krichevsky, D (2000). Impact of red palm oil on human nutrition and health.. Food Nutr. Bull. 21;182-188.

Kumar, R. Kumar, T. Kambjo, V. (2012). Pharmcological evaluation of Kigelia pinnata fruit extract against ethylene glycil induced urolithiasis in rats. Asian Journal of plant and Research; 2 (1); 63-72.

Lal S.D.and Yadar B.K. (1983). Folk medicines of kurushetra district. India Econ. Bot. 37:299305.

Lehninger, A.L., Nelson, D.L. Cox, M.M. (1993). Principles of Biochemistry, $5^{\text {th }}$ ed. New York; worth publishers, pp 259-263..

Malasky, B.R.and Alpert, J.S. (2002). Diagnosis of myocardial injury by biochemical markers: problems and promises. Cardiol Rev. 10 (5): 306-317.

Mozas, P. Albajar, M. Ross, E. (2002). A mutation in the promoter of the low density lipoprotein receptor gene associated with familial hypercholestolemia. Journal of Lipid Res. 43(1); 13-18.

Msouthi, J. D.and Mangombo, D., (1983). Medical herbs in Malawi and their uses. Hamdard 26:94-100.

Murray, R.K. Granner, D.K. ROdwell, V.W. (2006). Harpers Illustratd Biochemistry. $27^{\text {th }}$ ed. Lange medical publications.

Neuwinger, S. and Hutchings, A. (1996). African ethnobotany; poison and drugs. Chapman and hall.

Nevin K.G and Rajamohan T. (2006). Beneficial effect of virgin coconut oil on lipid parameters and in vitro LDL oxidation. Clinical Biochemistry, 37(9): 830-835.

Nevin K.G and Rajamohan T. (2009). Wet and dry extraction of coconut oil; impact on lipid metabolism and antioxidant status in cholesterol coadministered rats. Can $J$ Physiol. Pharm., 87;610.

Nevin K.G and Rajamohan T. (2004). Virgin coconut oil diet increase the antioxidant status in rats. Journal of Clinical Food Chemistry. 99:260-266.

Onyemaechi. O.A, Francis, I.D., Abraham, A.O. (2010). Prospective agent, Kigelia Africana fruit extract, against cisplatin induced kidney oxidant injury in sprague dawley rats. Asian journal of pharmaceutical and clinical Research; 3:84-88. 
Patel J. Kumar S. Patel H. (2012). Hypoglycemic and hypolipidemic activity of Amarantus viridis. Inter. J. pharm. Arch. $1(1) ; 1-6$.

Powell, E.E., Cooksely, W.G. Hanson, R. (1990). The natural history of nonalcoholic steatohepatitis: a follow-up study of fortytwo patients for up 21 years. Hepatology 1174-80.

Preeti K. and Asheesh K. (2 20111$)$. Antihyperlipidemic activity of aqueous extracts of fruit of Kigelia pinnata. Pharmacoline, 3;386-395.

Robert A.K.and Albert O (2003). Medical Management of Hyperlipidemia. $J$ of clinical Endocrinology and metabolism. 88;2445-2461.

Roberts W.C. (1995). Preventing and arresting coronary atherosclerosis. AM Heart J. 130;580-600.

Rojas, M. (2007). "Assessing the Engine performance of palm oil Biodiesel". Biodiesel. magazine.Retrieved; 25

Roodt, V. (1992). Kigelia Africana in the shell field Gride to the common Trees of the Moremi Game Resrve, Gborone, Botswana: Shell oil Botswana, pp 176-180.

Ross R. (1995) cell biology of atherosclerosis. Annu Rec Physio 157:791-804.

Ross, R. (1993) The Pathogenesis of Atherosclerosis: a Prospective for the 90s. Nutr 362:801-9

Satyyanarayana U. (2009). Biotechnology;. $2^{\text {nd }}$ ed. Books and Allied publishers; Kolkata India.

Segrest, J.P. Li. L. Harvey, S.C. (2000). Structure and function of apolipoprotein A-1 and high-density lipoprotein. Curr. Opin. Lipol. 11(2); 105-115.

Shah S. (2005). Virgin Coconut Oil, oil conquering various diseases Agromedia Pustaka.

Shalini K. Karva S.K. Vijusha M. (2014) Central nervous system activity of methanolic extract of Kigelia pinnata in experimental rats. Jof pharm and toxico. 4 (1), 48-53.

Shellard E.J. Evans W.C. Bradley P.R. (1980).
History of British Pharmacognosy. Pharm. $\mathrm{J} ; 225$

Shimokawa, H. Flavahan, N.A. Van, P.M (1991). Loss of endothelial pertussis toxin-sensitive $\mathrm{G}$-protein function in atherosclerotic porcine coronary artheries. Circ. Res. 83; 652-660

Sofowora, A. (1982). Medicinal plants and Traditional medicine in Africa, published by John wiley and Sons Ltd. Ist Edn, 131, 168171

Van, G. and Debruin, T. W. (1998). Chylomicron synthesis by instestinal cells in vitro and in vivo. Atherosclerosis; 141.

Vance D. E. and Vance J. E. (1996). Biochemistry of Kipids Lieaproteins and membranes. New York: Elsevier Science.

Vander, A. Sherman, J. Luciano, D. (2001). Human Physiology; the mechanism of body function $8^{\text {th }}$ ed. McGraw Hill publishers. New York:

Vane, J. R. Mitchell J. A. Appleton I, (1994). Inducible isoforms of cyclooxygenase and nitric oxide synthase in inflammation. Proc Natl Acad Sci USA; 91:2046-2050.

Vanhoutte, P.M. Ferrige, A.G. Moncada, S. (1995). Nitric oxide release account for the biological activity of endotheliumdependent responses in hypertension. Hypertens Res:, 18:87-998.

Vasudevan D.M and Sreekumari S. (2009). Text book of Biochemistry; $5^{\text {th }}$ ed. Jaypee publishers; New Delhi; India.

Vaziri, N.D. (2009). Causes of dsyregulation of lipid metabolism in chronic-renal failure. Semin Dial. 22(6):644:651.

Verma, D.D, Hartner, W.C. Golde, L.M. (2007). Protective effect of co-enzyme $\mathrm{Q}_{10}$-loaded liposome's on the myocardium in rabbits with an acute experimental myocardinal infarction pharm. Nes 24:2131-2137.

Zang, M. W, Zuccollo, A, Hou, X. Y., Nagata, D. (2004). AMP-activated protein kinase is required for the lipid-lowering effect of metformin in insulin-resistant human HepG2 cells. J Biol Chem 279:47898-47905. 